\title{
Analysis of Sociodemographic Characteristics of Early and Advanced Stage Chronic Kidney Disease Patients
}

\section{Erken ve İleri Evre Kronik Böbrek Hastalarının Sosyodemografik Özelliklerinin Analizi}

\author{
Ustun YILMAZ, Selin KIR, Ayca INCI, Nilgun AKSOY, Gulay DEMIRTAS, Semih GUL, Ummuhan MADEN
}

1 University of Health Sciences Antalya Training and Research Hospital, Nephrology, Antalya, Türkiye

2 University of Health Sciences Antalya Training and Research Hospital, Internal Medicine, Antalya, Türkiye

3 Akdeniz University Faculty of Nursing, Surgical Nursing, Antalya, Türkiye

Yazıșma Adresi

Correspondence Address

\section{Ustun YILMAZ}

University of Health Sciences

Antalya Training and Research

Hospital, Nephrology,

Antalya, Türkiye

ustunfy@gmail.com

Gelis tarihi / Received : Tem 28, 2020 Kabul tarihi / Accepted : Ara 11, 2020 Elektronik yayın tarihi : Eyl 01, 2021 Online published

Bu makalede yapılacak atıf: Cite this article as:

Yilmaz U, Kır S, Inci A, Aksoy N, Demirtas G, Gul S, Maden U.

Analysis of Sociodemographic Characteristics of Early and

Advanced Stage Chronic Kidney

Disease Patients

Akd Tip D / 2021; 7(3):424-429

Ustun YILMAZ

ORCID ID: 0000-0003-0237-0278 Selin KIR

ORCID ID: 0000-0001-7792-0882 Ayca INCI

ORCID ID: 0000-0002-7894-8913 Nilgun AKSOY

ORCID ID: 0000-0001-9038-3348 Gulay DEMIRTAS

ORCID ID: 0000-0001-5273-1452 Semih GUL

ORCID ID: 0000-0003-3494-3931

Ummuhan MADEN

ORCID ID: 0000-0002-9195-6918

\section{ABTRACT \\ Objective}

It was aimed to investigate sociodemographic features of chronic kidney disease patients, analyze difference of these features in early and advanced stage patients, find correctable factors that may change course of disease and to find new solutions in treatment and follow-up.

\section{Material and Methods}

Predialysis 345 patients diagnosed with chronic kidney disease were retrospectively analyzed. Patients were divided into early and advanced stages. Patients with Glomerular Filtration Rate 30 $\mathrm{ml} / \mathrm{min}$ were defined as early stage, $<30 \mathrm{ml} / \mathrm{min}$ as advanced stage. Sociodemographic and disease related features and laboratory parameters of patients were analyzed.

\section{Results}

In the study, $243(70.4 \%)$ patients were early stage and $102(29.6 \%)$ patients were advanced stage chronic kidney patients. Most common etiologies are; In early stage, chronic glomerulonephritis $(30.5 \%)$, diabetes mellitus $(16.9 \%)$ and genetic diseases $(16.0 \%)$, while at advanced stage, diabetes mellitus (34.3\%), hypertension (16.7\%) and unknown causes (15.7\%) were. Alcohol use was higher and regular drug use was lower in early stage patients compared to advanced stage patients. In advanced stage patients, habit of exercising regularly was found to be low compared to early stage patients.

\section{Conclusion}

It was found that there were correctable factors that could change course of disease. These factors differed in early and advanced stages. It is necessary to be aware of these factors for slower progressive of disease and take precautions for correctable factors from early stages of disease.

\section{Keywords}

Chronic kidney disease, Correctable factors, Sociodemographic feature 


\section{ÖZ}

\section{Amaç}

Kronik böbrek hastalarının sosyodemografik özelliklerinin araştırılması, erken ve ileri evre hastalarda bu özelliklerin farklılığının incelenmesi, hastalığın seyrini değiştirebilecek düzeltilebilir faktörlerin saptanması, tedavi ve takipte yeni çözümler bulunması amaçlanmıştır.

\section{Gereç ve Yöntemler}

Kronik böbrek hastalığı tanısı almış, prediyaliz 345 hasta retrospektif olarak incelenmiştir. Hastalar erken ve ileri evrelere ayrılmıştır. Glomerüler Filtrasyon Hızı $\geq 30 \mathrm{ml} / \mathrm{dk}$ olan hastalar erken , $<30 \mathrm{ml} / \mathrm{dk}$ olan hastalar ileri evre olarak tanımlandı. Hastaların sosyodemografik ve hastalıkla ilişkili özellikleri ile laboratuvar parametreleri analiz edilmiştir.

\section{Bulgular}

Çalışmada $243(\% 70,4)$ hasta erken evre (Evre 1-2-3), 102 $(\% 29,6)$ hasta ileri evre (Evre 4-5) kronik böbrek hastalığ1 olarak saptandi. En s1k görülen etyolojiler; erken evrede kronik glomerulonefrit $(\% 30,5)$, diabetes mellitus $(\% 16,9)$ ve genetik hastalıklar $(\% 16,0)$ iken ileri evrede diabetes mellitus $(\% 34,3)$, hipertansiyon $(\% 16,7)$ ve nedeni bilinmeyen $(\% 15,7)$ sebepler idi. Erken evre hastalarda ileri evre hastalara kıyasla alkol kullanımının daha yüksek, düzenli ilaç kullanımının daha düşük olduğu saptandı. İleri evre hastalarda ise düzenli egzersiz yapma alışkanlığ 1 erken evre hastalara göre düşük bulundu.

\section{Sonuç}

Hastalığın seyrini değiştirebilecek düzeltilebilir faktörlerin olduğu, erken ve ileri evrelerde bunların farklılık gösterebildiği görülmüştür. Daha yavaş progresyonlu hastalık seyri için bu faktörlerin farkında olunması ve hastalığın erken evrelerinden itibaren takip edilmesi önemlidir.

\section{Anahtar kelimeler}

Kronik Böbrek Hastalığı, Düzeltilebilir faktörler, Sosyodemografik özellikler

Ethical approval: This study was approved by the Ethics Committee of the Scientific Research Ethics Committee of Health Sciences University Antalya Training and Research Hospital for the study (Decision number: 10/22, decision date: 03/07/2020).

\section{INTRODUGTION}

Chronic kidney disease (CKD) is an important public health problem that has become almost epidemic in our country and in the world $(1,2,3)$. CKD is a progressive disease and has an important place in terms of both morbidity and mortality for patients. It is a disease that places a great burden on the health budget as well as being common. The most common etiology is diabetes mellitus (DM), followed by hypertension (HT). Apart from these, glomerulonephritis, kidney stones, genetic kidney diseases and systemic diseases with kidney involve- ment take place in etiology $(4,5,6)$. In the course of CKD; serious complications develop due to many reasons such as problems related to uremic toxins, endocrinological disorders, metabolic disorders and anemia, and patients quality of life, social life and productivity are severely damaged.

While CKD and its complications harm patients in many respects, low socioeconomic factors, bad habits, and negative living conditions have also been found to facilitate the progression of the disease $(7,8)$. Therefore, it is important to examine the sociodemographic characteristics of the patients. In our study, it was aimed to analyze the sociodemographic characteristics, laboratory parameters and etiologies of early and advanced CKD patients followed in our clinic and to identify correctable factors that may change the course of the disease.

\section{MATERIALS AND METHODS}

\section{Patients}

This study was conducted by retrospectively examining the files of 345 patients diagnosed with CKD who were followed up at the Nephrology clinic at the Health Sciences University Antalya Training and Research Hospital. Glomerular filtration rates (GFR) of patients; It was calculated using the formula 'Chronic kidney disease epidemiology collaboration' (CKD-EPI) (9). According to this calculation; Stage 1-2-3 patients with GFR $\geq 30 \mathrm{ml} / \mathrm{min}$ are defined as early stage, and Stage 4-5 patients with GFR $<30 \mathrm{ml} /$ min are defined as advanced stage. Being diagnosed with CKD for at least 3 months, no history of kidney transplant and being over 18 years old were determined as the inclusion criteria for the study. Those excluded from these parameters were not included in the study. Approval was obtained from the ethics committee of Health Sciences University Antalya Training and Research Hospital for the study (Decision number: 10/22, decision date: 03/07/2020). The study was conducted in accordance with the ethical standards defined in the 1964 Helsinki declaration.

\section{Statistical analysis}

SPSS (Statistical Package for Social Science) for Windows 23.0 was used for statistical analysis of the data obtained in the study. Descriptive analyzes were given with frequency distribution, mean and standard deviation. Initially, the normal distribution of data was tested using the Kolmogorov-Smirnov test. As a result of the tests performed, the properties of normally distributed data were analyzed by parametric tests, and those that did not, were analyzed by non-parametric tests. Difference of two independent averages of the groups was made by using "student $t$ test". In cases where parametric test assumptions were not provided, non-parametric alternative of this test, "Mann-Whitney U" was used. Pearson and Spearman correlation analysis was performed to determine the relationship between dependent quantitative variables. Statistical significance was accepted for $\mathrm{P}<0.05$ values. 


\section{RESULTS}

The study was performed in 345 patients with CKD who were at the pre-dialysis period at the Health Sciences University Antalya Training and Research Hospital. In our study, 243 $(70.4 \%)$ patients were found to be in the early stage (Stage $1-2-3)$, and $102(29.6 \%)$ patients were in the advanced stage (Stage 4-5). Sociodemographic characteristics of early and advanced stage patients are shown in Table I.

Table I. Distribution and comparison of socio-demographic and physical characteristics of patients by groups

\begin{tabular}{|c|c|c|c|c|}
\hline & $\begin{array}{l}\text { Stage 1-2-3 } \\
(\mathrm{n}=243)\end{array}$ & $\begin{array}{l}\text { Stage 4-5 } \\
(\mathrm{n}=102)\end{array}$ & & $\mathbf{p}$ \\
\hline $\begin{array}{l}\text { Age } \\
\text { (Mean } \pm \text { SD) }\end{array}$ & $49.06 \pm 14.52$ & $59.53 \pm 13.95$ & $Z=-6.028$ & $0.000^{*}$ \\
\hline Body mass index (Mean \pm SD) & $28.23 \pm 5.34$ & $27.90 \pm 4.99$ & $\mathrm{Z}=-\mathbf{0 . 2 8 0}$ & $0.779 *$ \\
\hline \multicolumn{5}{|l|}{ Gender (\%) } \\
\hline Female & $115(\% 47.33)$ & $38(\% 37.25)$ & \multirow{2}{*}{$x_{2}=2.95$} & \multirow{2}{*}{$0.086^{* *}$} \\
\hline Male & $128(\% 52.67)$ & $64(\% 62.75)$ & & \\
\hline \multicolumn{3}{|l|}{ Education status } & \multirow[t]{6}{*}{$x_{2}=8.28$} & \multirow[t]{6}{*}{$0.082 *$} \\
\hline Illiterate & $17(\% 6.99)$ & $14(\% 13.73)$ & & \\
\hline Elementary school & $110(\% 45.27)$ & $53(\% 51.96)$ & & \\
\hline Junior high school graduate & $27(\% 11.11)$ & $11(\% 10.78)$ & & \\
\hline High school graduate & $57(\% 23.46)$ & $14(\% 13.73)$ & & \\
\hline Graduated from a university & $32(\% 13.17)$ & $10(\% 9.80)$ & & \\
\hline \multicolumn{3}{|l|}{ Marital status } & \multirow[t]{3}{*}{$x_{2}=0.00$} & \multirow[t]{3}{*}{$0.986 * *$} \\
\hline Married & $188(\% 77.37)$ & $79(\% 77.45)$ & & \\
\hline Single & $55 / \% 22.63)$ & $23(\% 22.55)$ & & \\
\hline \multicolumn{3}{|l|}{ Home partner status } & \multirow{6}{*}{$x_{2}=7.348$} & \multirow[t]{6}{*}{$0.119^{* *}$} \\
\hline Lives with partner & $68(\% 27.98)$ & $31(\% 30.39)$ & & \\
\hline Lives with partner and children & $120(\% 49.38)$ & $49(\% 48.04)$ & & \\
\hline Lives alone & $18(\% 7.41)$ & $7(\% 6.86)$ & & \\
\hline Lives with children & $12(\% 4.94)$ & $11(\% 10.78)$ & & \\
\hline Lives with parents & $25(\% 10.29)$ & $4(\% 3.92)$ & & \\
\hline \multicolumn{5}{|l|}{ Settlement unit } \\
\hline City & $154(\% 63.37)$ & $56(\% 54.90)$ & $x_{2}^{2}=2.451$ & $0.294 * *$ \\
\hline District & $60(\% 24.69)$ & $33(\% 32.35)$ & & \\
\hline Village & $29(\% 11.93)$ & $13(\% 12.75)$ & & \\
\hline Home type & & & & \\
\hline Apartment & $162(\% 66.67)$ & $64(\% 62.75)$ & $x_{2}=0.489$ & $0.484^{* *}$ \\
\hline Detached house + other & $81(\% 33.33)$ & $38(\% 37.25)$ & & \\
\hline Home ownership status & & & & \\
\hline Rent & $76(\% 31.28)$ & $29(\% 28.43)$ & $x_{2}=1.640$ & $0.440^{* * *}$ \\
\hline Belongs to the family & $28(\% 11.52)$ & $8(\% 7.84)$ & & \\
\hline Own home & $139(\% 57.20)$ & $65(\% 63.73)$ & & \\
\hline Working status & & & & \\
\hline Bodily work & $72(\% 29.6)$ & $13(\% 12.7)$ & $x_{2}=13.998$ & $0.003 * *$ \\
\hline Retired & $51(\% 21.0)$ & $43(\% 42.2)$ & & \\
\hline Not working & $100(\% 41.2)$ & $36(\% 35.3)$ & & \\
\hline Desk job & $20(\% 8.2)$ & $10(\% 9.8)$ & & \\
\hline Income level status & & & & \\
\hline Under minimum wage & $57(\% 23.46)$ & $32(\% 31.37)$ & $x^{2}=3.272$ & $0.195 *$ \\
\hline Minimum wage & $118(\% 48.56)$ & $49(\% 48.04)$ & & \\
\hline Above minimum wage & $68(\% 27.98)$ & $21(\% 20.59)$ & & \\
\hline Smoking status & & & & \\
\hline Smoking & $67(\% 27.57)$ & $19(\% 18.62)$ & $x_{2}=5.637$ & $0.060 * *$ \\
\hline Never smoked & $133(\% 54.73)$ & $55(\% 53.92)$ & & \\
\hline Quit smoking & $43(\% 17.70)$ & $28(\% 27.45)$ & & \\
\hline Alcohol using status & & & & \\
\hline Yes & $39(\% 16.05)$ & $8(\% 7.84)$ & $x_{2}=4.112$ & 0.043 \\
\hline No & $204(\% 83.95)$ & $94(\% 92.16)$ & & \\
\hline Surgical history & & & & \\
\hline Yes & $131(\% 53.91)$ & $64(\% 62.75)$ & $x_{2}=2.282$ & $0.131^{* *}$ \\
\hline No & $112(\% 46.09)$ & $38(\% 37.25)$ & & \\
\hline Duration of kidney disease foll & & & & \\
\hline $0-6$ months & $115(\% 47.33)$ & $27(\% 26.47)$ & $x^{2}=19.971$ & $0.000^{* *}$ \\
\hline 6-12 months & $15(\% 6.17)$ & $8(\% 7.84)$ & & \\
\hline $1-6$ years & $56(\% 23.05)$ & $46(\% 45.10)$ & & \\
\hline 6 years and over & $57(\% 23.46)$ & $21(\% 20.59)$ & & \\
\hline Use of a walking aid device & & & & \\
\hline Yes & $11(\% 4.53)$ & $13(\% 12.75)$ & $x_{2}=7.497$ & 0.006 \\
\hline No & $232(\% 95.47)$ & $89(\% 87.25)$ & & \\
\hline Regular exercise status & & & & \\
\hline Yes & $108(\% 44.44)$ & $29(\% 28.43)$ & $x^{2}=7.695$ & $0.006^{m a}$ \\
\hline No & $135(\% 55.56)$ & $73(\% 71.57)$ & & \\
\hline Family history of kidney disea & & & & \\
\hline Yes & $90(\% 37.04)$ & $28(\% 27.45)$ & $x_{2}=2.934$ & $0.087^{* *}$ \\
\hline No & $153(\% 62.96)$ & $74(\% 72.55)$ & & \\
\hline Regular drug use status & & & & \\
\hline Yes & $214(\% 88.07)$ & $99(\% 97.06)$ & $x_{2}=6.905$ & $0.009 m$ \\
\hline No & $29(\% 11.93)$ & $3(\% 2.94)$ & & \\
\hline
\end{tabular}

*Mann-Whitney U test , ** Ch1-square test
The analysis showed that the average age of advanced stage CKD patients was higher $(\mathrm{Z}=-6.028 ; \mathrm{p}=.000)$. Gender and body mass index (BMI) parameters were not statistically different in early and advanced stage CKD patients ( $p>0.05)$. No statistically significant difference was found between the stages in terms of education status, marital status, home partner status, settlement unit, home type, home ownership status, income level status, smoking status, surgical history, family history of kidney disease $(p>0.05)$. While the rate of physical work was high in the early stage patients, the rate of retirement was found to be significantly higher in the advanced stage patients $\left(x^{2}=13.998 ; \mathrm{p}=0.003\right)$. Alcohol use was higher $\left(x^{2}=4.112 ; \mathrm{p}=0.043\right)$ and regular drug use was lower $\left(x^{2}=6.905 ; p=0.009\right)$ in the early stage compared to the advanced stage. In advanced stage patients, the habit of exercising regularly was lower compared to the early stage $\left(x^{2}=7.695 ; p=0.006\right)$, while use of a walking aid device $\left(x^{2}=7.497 ; p=0.006\right)$ was higher. Duration of kidney disease follow-up was determined to be concentrated between $0-6$ months in the early stage and 1-6 years in the advanced stage $\left(x^{2}=19.971 ; p=0.000\right)$.

Table II. Distribution of kidney disease causes by disease stage

\begin{tabular}{|l|l|l|}
\hline Kidney Disease Cause & $\begin{array}{l}\text { Stage 1-2-3 } \\
(\mathbf{n}=\mathbf{2 4 3})\end{array}$ & $\begin{array}{l}\text { Stage 4-5 } \\
(\mathbf{n}=\mathbf{1 0 2})\end{array}$ \\
\hline Chronic glomerulonephritis & $74(\% 30.5)$ & $8(\% 7.8)$ \\
\hline Congenital structural disorders & $2(\% 0.8)$ & - \\
\hline Stone or obstruction & $8(\% 3.3)$ & $6(\% 5.9)$ \\
\hline Hypertension & $26(\% 10.7)$ & $17(\% 16.7)$ \\
\hline Genetic diseases & $39(\% 16.0)$ & $9(\% 8.8)$ \\
\hline Diabetes mellitus & $41(\% 16.9)$ & $35(\% 34.3)$ \\
\hline Systemic diseases & $4(\% 1.6)$ & $4(\% 3.9)$ \\
\hline Urinary tract infection & $1(\% 0.4)$ & - \\
\hline Other reasons & $13(\% 5.3)$ & $7(\% 6.9)$ \\
\hline Reason unknown & $35(\% 14.4)$ & $16(\% 15.7)$ \\
\hline
\end{tabular}

The distribution of causes CKD by early and advanced groups is shown in Table II. In etiology, chronic glomerulonephritis $(30.5 \%)$, DM (16.9\%) and genetic diseases (16.0\%) were the most common causes of CKD in the early stage, while DM (34.3\%), HT (16.7\%) and unknown cause (15.7\%) were the most common causes in advanced stage.

When early and advanced stage CKD groups were compared in terms of laboratory parameters; creatinine $(Z=-14.147 ; \mathrm{P}=$ $0.000)$, phosphorus $(Z=-5.808 ; P=0.000)$, uric acid $(Z=$ -2.117; $\mathrm{P}=0.034)$, parathormone $(Z=-9.927 ; \mathrm{P}=0.000)$, ferritin $(Z=-4.761 ; P=0.000)$ and spot urine protein $(Z=$ -3.667; $\mathrm{P}=0.000$ ) averages were found to be significantly higher in the advanced stage. Calcium $(Z=-2.137 ; \mathrm{P}=0.033)$, GFR $(Z=-14.481 ; P=0.000)$ and hemoglobin $(F=0.078 ; P=$ 0.000 ) averages were found at a higher level in the early stage. It was found that there was no significant difference between the groups in terms of the average of albumin $(\mathrm{Z}=-1.333 ; \mathrm{P}=$ 0.183 ) level (Table III). 
Table III. Comparison of the laboratory parameters of the patients according to the stages

\begin{tabular}{|c|c|c|c|}
\hline Laboratory Parameters & $\begin{array}{l}\text { Stage 1-2-3 } \\
(\mathbf{n}=\mathbf{2 4 3}) \\
(\mathrm{Mean} \pm \mathrm{SD})\end{array}$ & $\begin{array}{l}\text { Stage 4-5 } \\
(\mathbf{n}=102) \\
(M e a n \pm S D)\end{array}$ & \\
\hline Creatinine (mg / dl) & $1.34 \pm 0.43$ & $2.93 \pm 0.80$ & $\begin{array}{l}Z=-14.147 \\
\mathbf{P}=\mathbf{0 . 0 0 0}\end{array}$ \\
\hline GFR $(\mathrm{ml} / \mathrm{min} / 1.73 \mathrm{~m} 2)$ & $62.53 \pm 26.69$ & $21.85 \pm 6.61$ & $\begin{array}{l}Z=-14.481 \\
\mathbf{P}=\mathbf{0 . 0 0 0}\end{array}$ \\
\hline Calcium (mg / dl) & $9.76 \pm 5.15$ & $9.27 \pm 0.70$ & $\begin{array}{l}Z=-2.137 \\
P=\mathbf{0 . 0 3 3}^{*}\end{array}$ \\
\hline Phosphorus (mg / dl) & $3.67 \pm 2.07$ & $4.09 \pm 0.83$ & $\begin{array}{l}Z=-5.808 \\
\mathbf{P}=\mathbf{0 . 0 0 0}\end{array}$ \\
\hline Albumin (g / dl) & $4.30 \pm 2.46$ & $4.13 \pm 0.47$ & $\begin{array}{l}\mathrm{Z}=-1.333 \\
\mathrm{P}=0.183^{*}\end{array}$ \\
\hline Uric acid (mg / dl) & $6.72 \pm 4.62$ & $6.97 \pm 1.69$ & $\begin{array}{l}Z=-2.117 \\
\mathbf{P}=\mathbf{0 . 0 3 4} \text { * }\end{array}$ \\
\hline Hemoglobin (g / dl) & $13.08 \pm 1.89$ & $11.90 \pm 1.78$ & $\begin{array}{l}\mathrm{F}=0.078 \\
\mathrm{P}=\mathbf{0 . 0 0 0}\end{array}$ \\
\hline Parathormon $(\mathrm{pg} / \mathrm{ml})$ & $72.16 \pm 61.85$ & $188.32 \pm 124.92$ & $\begin{array}{l}Z=-9.927 \\
\mathbf{P}=\mathbf{0 . 0 0 0}\end{array}$ \\
\hline Ferritin (mcg / l) & $69.55 \pm 76.38$ & $108.99 \pm 103.99$ & $\begin{array}{l}Z=-4.761 \\
\mathbf{P}=\mathbf{0 . 0 0 0}\end{array}$ \\
\hline Spot urine protein $(\mathrm{mg} / \mathrm{g})$ & $1.98 \pm 3.28$ & $2.52 \pm 2.97$ & $\begin{array}{l}Z=-3.667 \\
\mathbf{P}=\mathbf{0 . 0 0 0 *}\end{array}$ \\
\hline
\end{tabular}

*Mann-Whitney U testi

**Independent Samples T Test

When correlation analysis between CKD disease stage and laboratory parameters is made; creatinine $(\mathrm{r}=0.763 ; \mathrm{p}$ $<0.001)$, phosphorus $(\mathrm{r}=0.313 ; \mathrm{p}<0.001)$, uric acid $(\mathrm{r}=$ $0.114 ; \mathrm{p}=0.034)$, parathormone $(\mathrm{r}=0.535 ; \mathrm{p}<0.001)$, ferritin $(\mathrm{r}=0.257 ; \mathrm{p}<0.001)$ and spot urine protein $(\mathrm{r}=0.198 ; \mathrm{p}$ $<0.001)$ statistically significant positive correlation was found. Mean levels of hemoglobin $(r=-0.279 ; p<0.001)$, GFR $(\mathrm{R}=-0.781 ; \mathrm{p}<0.001)$ and calcium $(\mathrm{R}=-0.115 ; \mathrm{p}<$ $0.001)$ were statistically significant negative correlations between the disease stage.

\section{DISGUSSION}

It is a disease that should be taken seriously in terms of the burden of CKD costs on the countries and the increasing frequency of them. Therefore, it seems important to take precautions according to the results that may change the course of the disease as a result of examining the life styles, social status, habits, kidney disease causes, and biochemical disorders related to the disease. In our study, we examined the sociodemographic features and laboratory parameters of our patients diagnosed with predialysis CKD, which were followed up in our clinic, for early and advanced stages.

In our study, we found that the average age of patients with advanced stage was higher. This finding is in line with the information that advancing age is a risk factor for chronic kidney diseases $(10,11)$.

It has been reported that weight gain increases the risk of CKD, even if it falls within the normal BMI limits (12). In addition, in patients who have not started renal replacement therapy, it was determined that oral intake began to deteriorate when GFR decreased below $50 \mathrm{ml} / \mathrm{min}$, impaired renal function increased and provided the basis for malnutrition (13). In our study, no difference was found between BMI according to disease stages.

In the CREDIT study conducted in our country, female gender was found to be a risk factor for CKD (3). In another study, male gender (70.7\%) was found in the majority (14). In our study, no difference was found in terms of gender in both early and advanced stages.

Increasing the level of education; Adopting a lifestyle that will prevent the development of many systemic diseases known to be included in the CKD etiology is an important factor in terms of having disease awareness and compliance with treatment. In some studies supporting this situation, low level of education has been reported to be a risk factor for CKD (10). In our study, no difference in education level was found between early and advanced stage CKD patients.

In a study conducted by Inci et al., It was stated that parameters such as the patient's home partner status, settlement unit, home type, home ownership status, income level did not differ between the disease stages (15). Similarly, in our study, no difference was found between these parameters and disease stages.

CKD is a disease that leads to significant loss of labor and associated decline in income. In our study, no difference was observed in the income levels of patients according to the stages. The reason for this may be that the income level was offset due to the high rate of physical work of early stage patients and the high number of retirements in advanced stage patients.

In a study, smoking and alcohol use have been reported to accelerate CKD development and disease progression (16). In our study, we found that while the rate of those who smoke in the early stages is high, the percentage of those who quit smoking in the advanced stage is high, but there is no statistical difference between the stages. We found that alcohol use was significantly higher in the early stages. This may be associated with a decrease in alcohol use behavior due to low awareness of the disease at the early stage or due to increased anxiety with disease progression.

In our study, it was found that after the diagnosis of CKD, the duration of kidney disease follow-up was concentrated in 0-6 months in the early stage patients, and in 1-6 years in the advanced stage patients. Long follow-up in advanced stage patients is an expected finding.

In our study, use of a walking aid device was significantly more frequent in advanced stage patients. This need is thought to occur due to the advanced complications of CKD disease and additional medical problems brought about by the increase in age.

It has been reported that a moderate exercise is recommended in patients with $\mathrm{CKD}$, since it reduces bone and joint diseases and cardiovascular risk caused by age (17). In our study, regular exercise was found to be higher in the early stage, while the rate of regular exercise decreased as the disease stage progressed.

Family history of kidney disease was similarly detected in early and advanced stage patients. This is an expected finding. When studies on regular drug use were examined; It has been reported that the level of importance that individuals attach to their illness and not knowing the drug benefits due to lack of education affect adherence to treatment $(18,19)$. In our study, it was found that regular drug use was higher in advanced 
CKD patients. The reason for this situation may be due to factors such as those with early stage disease not being able to grasp the importance of the disease or not knowing the benefit of the drug for the disease.

Among the causes leading to chronic kidney failure, DM, HT and glomerulonephritis was reported as the first three causes (4-6). When the causes leading to kidney disease were examined in our study; the three most common etiologies; while chronic glomerulonephritis was 30.5\%, DM 16.9\% and genetic diseases were $16.0 \%$ in early stage patients, DM was $34.3 \%$, HT $16.7 \%$ and unknown reason $15.7 \%$ in advanced stage patients. Glomerulonephritis and genetic-induced kidney diseases may have caused an early and advanced etiological factor difference due to their early follow-up in our clinic.

In our study, it was observed that the level of creatinine, phosphorus, parathormone, uric acid, ferritin and spot urine proeinuria was higher in advanced stage patients and positively correlated with the disease stage. GFR, calcium, hemoglobin levels were found to be low in advanced stage and negatively correlated with disease stage. Although albumin levels were found to be relatively lower in advanced stage, there was no statistically difference between stages. These findings were found to be compatible with the literature $(1,20)$.

Due to the fact that some patients received a diagnosis in an external center and then began to follow up to our clinic, the inability to reach all of the GFR values at the time of diagnosis, the fact that it is single-center and cross-sectional, can be shown among the limitations of our study.

\section{GONGLUSIONS}

In our study, the three most common etiologies in CKD are; while chronic glomerulonephritis, DM and genetic diseases were detected in early stage patients, DM, HT and unknown causes were found in advanced stage patients. It was found that the average age of patients with advanced stage, the use of a walking aid device was higher and the regular exercise rate was lower in these patients. In early stage patients, it was observed that alcohol use was high and regular drug use was lower. These findings indicate that there are correctable causes that can cause this disease to progress. These factors differed in early and advanced stages. It is necessary to be aware of these factors for slower progressive of the disease and take precautions for correctable factors from early stages of disease. Our study and new studies to be conducted in a multi-centered manner with more patients will illuminate this issue more and will guide the follow-up of this disease.

Competing interests: The authors declare that they have no competing interest.

Financial Disclosure: There are no financial supports.

Ethical approval: This study was approved by the Ethics Committee of the Scientific Research Ethics Committee of Health Sciences University Antalya Training and Research Hospital for the study (Decision number: 10/22, decision date: 03/07/2020).

\section{REFERENGES}

1. Levey AS, Coresh J. Chronic kidney disease. Lancet 2012; 14;379(9811):165-80.

2. Süleymanlar G. Kronik Böbrek Hastalığı ve Yetmezliği: Tanımı, Evreleri ve Epidemiyolojisi. Türkiye Klin J Int Med Sci 2007; 3(38).

3. Süleymanlar G, Utaş C, Arinsoy T, Ateş K, Altun B, Altiparmak MR, Ecder T, Yilmaz ME, Çamsari T, Başçi A, Odabas AR, Serdengeçti K. A population-based survey of Chronic REnal Disease In Turkey--the CREDIT study. Nephrol Dial Transplant 2011; 26(6):1862-71.

4. National Kidney Foundation. K/DOQI Clinical Practice Guidelines for Chronic Kidney Disease: Evaluation, Clasification and Stratification. Am J Kidney Dis 2002; 39(2 Suppl 1):S1-266.

5. Hart PD, Bakris GL. Hypertensive nephropathy: preven tion and treatment recommendations. Expert Opin Pharmacother 2010; 11(16):2675-86.

6. Jha V, Garcia-Garcia G, Iseki K, Li Z, Naicker S, Plattner B, Saran R, Yee-Moon Wang A, Yang CW. Chronic kidney disease: global dimension and perspectives. Lancet. 2013; 382(9888):260-72.

7. Naicker S. End-stage renal disease in sub-Saharan and South Africa. Kidney Int Suppl 2003; (83):S119-22.

8. Zeng X, Liu J, Tao S, Hong HG, Li Y, Fu P. Associations between socioeconomic status and chronic kidney disease: a meta-analysis. J Epidemiol Community Health 2018; 72(4):270-279.

9. Levey AS, Stevens LA, Schmid CH, Zhang YL, Castro AF 3rd, Feldman HI, Kusek JW, Eggers P, Van Lente F, Greene T, Coresh J. A new equation to estimate glomeru lar filtration rate. Ann Intern Med 2009; 150(9):604-12.

10. Bartmańska M, Więcek A. Chronic kidney disease and the aging population. G Ital Nefrol 2016; 33 Suppl 66:33.S66.11.

11. Levey AS, Coresh J, Balk E, Kausz AT, Levin A, Steffes MW, Hogg RJ, Perrone RD, Lau J, Eknoyan G. National Kidney Foundation practice guidelines for chronic kidney disease: evaluation, classification, and stratifica tion. Ann Intern Med 2003; 139(2):137-47.

12. Ryu S, Chang Y, Woo HY, Kim SG, Kim DI, Kim WS, Suh BS, Choi NK, Lee JT. Changes in body weight predict CKD in healthy men. J Am Soc Nephrol 2008; 19(9):1798-805.

13. Mehrotra R, Kopple JD. Nutritional management of maintenance dialysis patients: why aren't we doing better? Annu Rev Nutr 2001; 21: 343-79.

14. Ladi-Akinyemi TW, Ajayi I. Risk factors for chronic kidney disease among patients at oabisi onabanjo univer sity teaching hospital in sagamu, Nigeria: A retrospective cohort study. Malawi Med J 2017; 29(2):166-170.

15. İnci A, Çoban M, Sarıkaya M, Maden Ü. Prediyaliz Kronik Böbrek Hastalarında Kesitsel Bir Çalışma: Yaşam Kalitesi ve Etkileyen Faktörler. Kocatepe Tıp Dergisi 2017; 18:130-135

16. Shankar A, Klein R, Klein BE. The association among 
Yilmaz U. et al

smoking, heavy drinking, and chronic kidney disease.

Am J Epidemiol 2006; 164(3):263-71.

17. Taş D, Akyol A. Egzersiz ve Kronik Böbrek Yetmezliği. Türk Nefroloji, Diyaliz ve Transplantasyon Hemşireleri Derneği Nefroloji Hemşireliği Dergisi 2017:1 (12).

18. Kamran A, Sadeghieh Ahari S, Biria M, Malepour A, Heydari H. Determinants of patient's adherence to hyper tension medications: application of health belief model among rural patients. Ann Med Health Sci Res 2014;4(6):922-7.

19. Yakar B, Demir M. Kronik Böbrek Yetmezliği Olan Hastalarda Antihipertansif İlaç Tedavisine Uyum Oran ları ve Etkileyen Faktörlerin Araştırılması. Dicle Tıp Dergisi / Dicle Med J 2019; 46 (4) : 685 - 696.

20. Akpolat T, Utaş C, Süleymanlar G. Nefroloji El Kitabı, 4.baskı. İstanbul: Nobel Tıp Kitabevi, 2007, sayfa 283-323. 